\title{
TANTANGAN DAN PELUANG PENEGAKAN HUKUM DALAM PEMBERANTASAN TINDAK PIDANA KORUPSI
}

\author{
Martini \\ Fakultas Hukum Universitas Muhammadiyah Palembang dan advokat \\ Email: tiyoalfarez @gmail.com
}

\begin{abstract}
The challenges of law enforcement in eradicating corruption are among others: the lack of trust in law enforcement officers; Examination of corruption cases in court by judges prioritizes the fulfillment of formal legal actions. The absence of a judge's decision which is a symbol of firmness in combating corruption: awareness of the impact of corruption is still too abstract and poorly understood by the community; The war on corruption is still merely a political discourse or entertainment for the people; the absence or lack of opportunities to participate in eradicating corruption is the reason why people do not care or are concerned about eradicating corruption. Besides the inherent habit that bahwa if all want to be fast, money is the solution 'and culture that is ' nrimo 'or does not want to question all matters related to the administration of the state, as if it is an element of fertilization. Opportunities for law enforcement in eradicating corruption include: Issuance of Law No. 31 of 1999 concerning Eradication of Corruption Crime; the growth of the Corruption Perception Index (CPI) in Indonesia is the highest compared to other countries in the world; national concerns about corruption can stimulate governments and anti-corruption activists to campaign extensively with high intensity; The press has become a powerful media for raising public awareness of the effects of corruption.
\end{abstract}

Key Words: law enforcement, eradicating corruption.

\begin{abstract}
ABSTRAK
Tantangan penegakan hukum dalam memberantas korupsi antara lain: kurangnya kepercayaan pada petugas penegak hukum; Pemeriksaan kasus korupsi di pengadilan oleh hakim memprioritaskan pemenuhan tindakan hukum formal. Tidak adanya keputusan hakim yang merupakan simbol ketegasan dalam memberantas korupsi: kesadaran akan dampak korupsi masih terlalu abstrak dan kurang dipahami oleh masyarakat; Perang melawan korupsi masih sebatas wacana politik atau hiburan bagi rakyat; tidak adanya atau kurangnya kesempatan untuk berpartisipasi dalam memberantas korupsi adalah alasan mengapa orang tidak peduli atau khawatir tentang pemberantasan korupsi. Selain kebiasaan yang melekat bahwa jika semua ingin cepat, uang adalah solusi 'dan budaya yang' nrimo 'atau tidak ingin mempertanyakan semua hal yang berkaitan dengan administrasi negara, seolah-olah itu adalah unsur pemupukan. Peluang untuk penegakan hukum dalam memberantas korupsi meliputi: Penerbitan Undang Undang Nomor 31 Tahun 1999 tentang Pemberantasan Tindak Pidana Korupsi; pertumbuhan Indeks Persepsi Korupsi (CPI) di Indonesia adalah yang tertinggi dibandingkan dengan negara-negara lain di dunia; kekhawatiran nasional tentang korupsi dapat merangsang pemerintah dan aktivis anti-korupsi untuk berkampanye secara luas dengan intensitas tinggi; Pers telah menjadi media yang kuat untuk meningkatkan kesadaran publik tentang dampak korupsi.
\end{abstract}

Kata Kunci: Penegakan Hukum, Pemberantasan Korupsi

\section{PENDAHULUAN}

\section{A. Latar Belakang}

Korupsi adalah perilaku yang merusak sistem sosial. Berbagai keputusan penting demi kepentingan orang banyak diambil berdasarkan pertimbangan dan kepentingan pribadi, tanpa mempedulikan akibat sosialnya bagi kehidupan masyarakat banyak. Jika tidak dikendalikan, korupsi dapat mengancam lembaga-lembaga demo- krasi dan ekonomi pasar. Kebijakan politik dan sistem hukum disusun untuk 
melindungi elite politik yang korup, sekaligus menjadi alat untuk menghancurkan kekuatan sosial masyarakat yang ingin melawan. ${ }^{1}$

Dalam pengertian sederhana, korupsi adalah penyalahgunaan kekuasaan dan kepercayaan untuk kepentingan pribadi. Karena itu korupsi dipahami dalam konteks perilaku pejabat-pejabat sektor publik - politisi, pegawai negeri yang memakai kekuasaan dan wewenang sosial untuk memperkaya diri, atau bersama orang-or- ang yang dekat dengan mereka.

Korupsi makin mudah ditemukan di berbagai bidang kehidupan. Pertama, karena melemahnya nilai-nilai sosial, kepentingan pribadi menjadi lebih utama dibanding kepentingan umum, serta kepemilikan benda secara individual menjadi etika pribadi yang melandasi prilaku sosial sebagaian besar orang. Kedua, tidak ada transparansi dan tanggung gugat sistem integritas publik. Birokrasi pelayanan publik justru digunakan oleh pejabat publik untuk mengejar ambisi politik pribadi, semata-mata demi promosi jabatan dan kenaikan pangkat. Sementara kualitas dan kuantitas pelayanan publik, bukan prioritas dan orientasi yang utama.

\section{B. Permasalahan}

Pokok permasalahan yang akan dibahas dalam makalah ini adalah : Bagaimana tantangan dan peluang penegakan hukum dalam pemberantasan tindak pidana korupsi?

\section{Metode Penulisan}

Penulisan makalah ini menggunakan metode analisis SWOT (Strenght, Weakness, Opportunity and Threat). Penulis menggabungkan Weakness and Threat menjadi 'Tantangan, dan Strenght, and Opportunity menjadi 'Peluang'. Penulis sengaja membahas tantangan penegakan hukum dalam pemberantasan tindak pidana korupsi terlebih dahulu baru kemudian membahas peluangnya.

\section{PEMBAHASAN}

\section{A. Tantangan Penegakan Hukum dalam Pemberantasan Tindak Pidana Korupsi}

Sebelum membentuk Komisi Pemberantasan Korupsi (KPK), pemeritah Indonesia telah membentuk 7 lembaga anti

\footnotetext{
${ }^{1}$ Jeremy Pope, Strategi Memberantas Korupsi, alih bahasa Masri Maris, ditertibkan atas kerjasama Transparency International Indonesia dengan Yayasan Obor Indonesia dan TI Indonesia, Jakarta, 2008.
}

korupsi. Semua lembaga anti korupsi yang dibentuk tersebut, umurnya tidak ada yang melebih tiga tahun, lembaga anti korupsi tersebut lansung dileburkan lagi oleh pemegang kepentingan.

Fenomena korupsi telah menjadi konsumsi keseharian rakyat Indonesia ketika membaca lembaran surat kabar atau melihat pemuatan informasi di media elektronik. Intensitas pers dalam memberitakan kasuskasus korupsi seolah-olah berkejaran dengan pengungkapan kasus-kasus korupsi oleh aparat penegak hukum. Kasus korupsi yang satu terungkap diikuti dengan kasus korupsi yang lain, terus menerus seperti cerita bersambung yang belum diketahui the end of story-nya. Masih banyak kasus korupsi yang menjadi pekerjaan rumah bagi aparat penegak hukum menunggu untuk diungkap. Apa yang sebenarnya terjadi pada masyarakat kita? Apakah rakyat kita yang menjadi pejabat publik telah mengalami dekadensi moral sehingga begitu permisif terhadap perilaku yang merugikan kepentingan umum? Dalam perspektif religius, perilaku korupsi menafikan keberadaan Tuhan dan mengingkari hukum Tuhan agar dilaksanakan oleh pengikutnya. Ataukah berkaitan dengan belum adanya contoh kasus yang dapat mentransformasikan efek penjera (deterent effect ) bagi calon-calon pelaku korupsi. Pernyataan yang terakhir berada dalam perspektif hukum bahwa hukum belum mampu mencegah merebaknya praktek korupsi dan memberikan ganjaran ( punishment ) yang setimpal terhadap pelaku korupsi.

Terjadi suatu ironi dalam pemberantasan korupsi di Indonesia saat ini, yaitu disatu pihak pemerintahan sangat gencar melakukan penegakan hukum kasus-kasus korupsi tetapi dipihak lain kasus korupsi terus muncul silih berganti. Kemudian muncul sorotan terhadap aparat penegak hukum yang menjadi avant garde penegakan hukum, dan sekaligus menjadi harapan akan tegaknya hukum terhadap para pelaku korupsi. Sorotan terhadap penegak hukum karena secara teoritis dan praktis penegakan hukum sangat tergantung bagaimana aparat penegak hukum dalam upayanya menegakan hukum dengan menjebloskannya ke penjara. 
Pemeriksaan kasus tindak pidana korupsi di pengadilan oleh hakim lebih memprioritaskan pada pemenuhan perbuatan melawan hukum formil. Hakim cenderung untuk melihat apakah suatu perbuatan terdakwa telah memenuhi perbuatan hukum formil dari pada perbuatan melawan hukum materiil. Kecenderungan tersebut adalah mengandalkan pembuktian kerugian keuangan negara pada hasil audit BPKP atau hakim akan meminta hasil audit dari badan pengawas keuangan pemerintah. Atau hakim akan memeriksa suatu tindakan yang dituduhkan sebagai korupsi dilakukan dengan menyimpang atau menyalahi prosedur/ketentuan yang berlaku. Penilaian terhadap suatu perbuatan apakah sudah sesuai dengan prosedur atau tidak menjadi salah satu bentuk untuk mencari perbuatan melawan hukum formil. Putusan hakim terhadap tindak pidana korupsi cenderung mengedepankan perbuatan melawan hukum formil. Hakim jarang menggunakan pertimbangan hukum (legal reasoning) dalam putusan dengan analisis perbuatan melawan hukum materiil. Perbuatan melawan hukum materiil digunakan sebagai unsur pemberat dalam penjatuhan pidana, misalnya bahwa terdakwa adalah pejabat negara yang seharusnya memberik teladan atau koruptor belum pernah dipidana.

Meskipun telah ada kesepakatan (consent) antara DPR dan Presiden bahwa korupsi adalah kejahatan luar biasa (extraordinary crime) belum cukup untuk mencegah pejabat publik untuk tidak melakukan korupsi. Ketiadaan putusan hakim yang menjadi simbol ketegasan dalam pemberantasan korupsi menjadi salah satu alasan mengapa korupsi tetap berlangsung dan seolah-olah membuat pejabat publik tidak takut terhadap hukum. Karena tidak cukup dengan menyatakan bahwa korupsi merupakan kejahatan luar biasa, tanpa pernah memberikan informasi kepada rakyat dampak dari korupsi. Korupsi belum menjadi keprihatinan nasional artinya pertama, bahwa yang melihat bahwa korupsi sebagai sesuatu yang perlu diberantas hanya kelompok masyarakat tertentu. Sehingga tekanan politik yang bersifat massive masih didominasi oleh elemen tertentu seperti mahasiswa dan LSM. ${ }^{2}$

Meskipun dapat dikatakan bahwa kelompok masyarakat atau civil society mewakili kepentingan masyarakat luas tetapi kesadaran akan dampak korupsi masih terlalu abstrak dan kurang dipahami masyarakat. Tanpa mengecilkan kontribusi peran mahasiswa dan LSM dalam memperjuangkan pemberantasan korupsi, tapi apabila dampak korupsi dapat dilihat seperti dampak bencana tsunami yang melahirkan kesadaran bersama untuk membantu para korban tsunami melintasi batas-batas suku, agama, ideologi dan golongan maka akan menghasilkan gelombang pemberantasan korupsi yang luar biasa.

Korupsi merupakan bentuk manipulasi terhadap pajak yang diperoleh dari rakyat atau utang luar negeri yang nantinya akan dibebankan pada rakyat. Elaborasi dampak korupsi memegang peranan penting dalam melahirkan keprihatinan nasional terhadap korupsi. Selain itu setelah dinyatakan sebagai extraordinary crime maka menjadi tugas pemerintah untuk melakukan extraordinary accomplishment untuk memberantas korupsi. Perang terhadap korupsi masih sekedar menjadi wacana atau hiburan politis bagi rakyat. pemberantasan korupsi masih diwacanakan dalam aras penegakan hukum karena putusan hakim yang memenuhi rasa keadilan rakyat belum muncul. Putusan hakim tidak hanya sekedar melihat terpenuhinya unsur-unsur korupsi dalam UU Korupsi, melainkan dibutuhkan pertimbangan dampak dari suatu perbuatan yang dilakukan oleh pejabat publik. Dan juga kemungkikan lahirnya pengaruh penjeraan dari putusan hakim.

Selain itu, ketiadaan atau minimnya kesempatan untuk berpartisipasi dalam pemberantasan korupsi menjadi penyebab masyarakat tidak peduli atau prihatin terhadap pemberantasan korupsi. Masyarakat yang

\footnotetext{
${ }^{2}$ Yakub Adi Krisanto, Tindak Pidana Korupsi, (Usaha) Penegakan Hukum di Republik Korup, Academia, diakses tanggal 21 Januari 2019
} 
sudah terkontaminasi dengan pragmatisme hanya akan peduli apabila masalah-masalah masyarakat berkaitan langsung terhadap kepentingan individu. Atau apabila dampak korupsi akan mempengaruhi keberadaan individu baik secara sosial maupun ekonomi. Ketidakpedulian masyarakat dimanfaatkan oleh pejabat publik untuk melakukan manipulasi-manipulasi terhadap kegiatan yang menyangkut kepentingan masyarakat. Salah satu metode yang efektif untuk mengungkapkan kasus korupsi adalah laporan dari lingkungan internal organisasi dalam suatu jejaring kekuasaan. Kelemahan metode ini adalah apabila terdapat mutual consensus dari lingkungan tersebut untuk bahu membahu menutup-nutupi korupsi yang terjadi. Akses partisipasi perlu dibuka bahkan dipermudah untuk lebih optimalnya pemberantasan korupsi. Karena masyarakat merupakan sumber daya yang mempunyai ketersediaan informasi yang melimpah. Partisipasi dalam konteks pemberantasan korupsi membutuhkan edukasi dan pemberdayaan. Artinya masyarakat perlu diedukasi mengenai dampak korupsi dan urgensi dari pemberantasan korupsi, sekaligus memberdayakan diri untuk berani memberikan laporan kepada aparat penegak hukum. Partisipasi rakyat juga membutuhkan sikap tanggap dan positif (responsive attitude) dari aparat penegak hukum ketika rakyat melaporkan adanya indikasi korupsi. Meskipun komitmen pemberantasan korupsi pada pemerintahan sangat kuat, namun kenyataan praktek korupsi tetap ada dan langkah-langkah untuk mencegah atau menghambat korupsi masih membutuhkan langkah panjang.

Adanya gejala umum bahwa aparat penegak hukum dalam penegakan hukum pemberantasan korupsi lebih memfokuskan pada aspek formil dari suatu tindak pidana. Gejala umum tersebut semakin menegaskan aspek formil dari penegakan hukum. Untuk itu pertanyaanya apakah putusan MK tersebut bertentangan dengan penegakan hukum pemberantasan korupsi yang selama ini dipraktekkan? Ataukah putusan tersebut akan menghambat upaya pemberantasan korupsi di Indonesia? Putusan MK menjadi afirmasi penegakan hukum dan tulisan ini merupakan sindiran bagi Jaksa Agung bahwa aparat kejaksaan dalam mengusut kasus korupsi lebih mengandalkan pencarian bukti formil dan tidak berani mengungkapkan bukti materiil dari suatu perbuatan yang dilakukan oleh koruptor. Aparat penegak hukum harus berefleksi terhadap putusan $\mathrm{MK}$ tersebut. Putusan MK akan mudah distigmatisasi sebagai pendukung aliran legalistik. Tetapi putusan MK lebih mengacu pada kepastian hukum yang adil dengan asumsi bahwa pertama, hukum diadakan harus dapat menjamin kehakekatannya yaitu menciptakan keadilan dan kepastian. Hukum harus mengandung keadilan dan kepastian, sehingga apabila tidak terkandung keadilan dan kepastian maka tidak dapat dikatakan sebagai hukum. Inilah yang menjadi titik tolak pandangan MK bahwa penjelasan Pasal 2 ayat (1) UU Pemberantasan Tindak Pidana Korupsi (UU PTPK) tidak dapat menjadi kepastian hukum' yang adil.

Aparat penegak hukum tidak perlu berapriori terhadap putusan $\mathrm{MK}$ karena putusan tersebut hanya merupakan penegasan dari praktek penegakan hukum yang selama ini dilaksanakan pada upaya pemberantasan korupsi. Sehingga putusan MK menjadi penguat untuk menyakinkan langkah-langkah hukum yang sudah ditempuh dalam pemberantasan korupsi. Tetapi perlu diingat bahwa putusan MK memberikan suatu terobosan hukum khususnya bagi hakim yang mengadili kasus tindak pidana korupsi. Dimana bahwa terpenuhinya unsur memperkaya diri sendiri, orang lain atau korporasi sudah cukup untuk melakukan pemidanaan koruptor. Bahwa peraturan perundang-undangan pemberantasan korupsi sudah sedemikian rupa dibentuk agar dapat mencapai tujuan utamanya yaitu memberantas korupsi. Namun dalam penegakan hukumnya terdapat kompleksitas baik dari aparat penegak hukumnya maupun budaya hukumnya. Penegakan hukum baik yang dilakukan oleh POLRI dan Kejaksaan maupun KPK bertemu dengan budaya hukum yang seolah terlanjur berwatak korup. Artinya bahwa dengan dipengaruhi oleh konsumerisme atau pemujaan terhadap materi maka segala cara dihalalkan asalkan dapat mencapai keterpenuhan materi. Pertemuan ini juga terjadi ketika masyarakat mengalami keadaan yang ingin selalu cepat. 
Apakah itu disebut budaya instan atau potong jalur, keinginan untuk selalu cepat dan dinomorsatukan langsung atau tidak langsung berkontribusi pada terjadinya korupsi.

Selain itu kebiasaan yang sudah melekat bahwa 'kalau semua ingin cepat, uang adalah solusinya', seolah menjadi unsur penyubur dari tumbuh-kembangnya korupsi. Kemudian budaya yang 'nrimo' atau tidak mau mempermasalahkan segala urusan yang ada kaitannya dengan penyelenggaraan negara juga mendorong terjadinya korupsi. Hukum adalah bagian dari budaya masyarakat. Ketika peraturan perundang-undangan bertujuan memberantas korupsi berhadapan dengan budaya (hukum) yang menyuburkan korupsi maka 'pertarungan' tersebut membutuhkan energy social dan ekonomi yang luar biasa.

\section{B. Peluang Penegakan Hukum dalam Pemberantasan Tindak Pidana Korupsi}

Salah satu buah reformasi pada tahun 1999 adalah diterbitkannya UU No. 31 Tahun 1999 tentang Pemberantasan Tindak Pidana Korupsi. Undang-undang tersebut menjadi tonggak bersejarah bagi hukum di Indonesia, pertama, bertolak dari nama atau judul undang-undangnya dapat diketahui bahwa adanya kesadaran dari DPR yang menjadi representasi rakyat Indonesia mengenai perlunya pemberantasan korupsi. Kedua, kesadaran perlunya pemberantasan korupsi dilatar belakangi dengan kondisi negara pada saat itu korupsi (bahkan sampai saat ini) sangat dirasakan oleh masyarakat di republik ini. Indonesia yang pada saat itu baru saja keluar dari rejim orde baru yang korup berkehendak untuk memperbaiki kondisi bangsa. Slogan anti korupsi, kolusi dan nepotisme atau dikenal dengan KKN sangat populer di perbincangkan masyarakat. Pembicaraan masyarakat mengenai KKN menunjukkan bahwa korupsi menjadi bagian yang sudah menjadi rahasia umum. Praktek penyelenggaraan negara yang KKN kasat mata dapat diindera oleh rakyat, uang pelicin atau suap atau sogokan adalah istilah-istilah yang menggambarkan adanya KKN di republik ini. ketiga, untuk itu pembentuk undang-undang melihat bahwa KKN berkontribusi pada pelemahan ekonomi nasional, dalam hal adanya pelemahan efisiensi bagi daya saing industri di Indonesia.

Senada dengan itu, Prof. Saldi Isra, salah seorang pendiri Integritas di Sumbar, juga menyebut upaya Indonesia memberantas korupsi hingga tahun tahun 2015 cukup menunjukkan hasil. Hal ini tidak lepas dari peran sentral KPK sebagai lembaga pemberantas korupsi. Ketika KPK dibentuk Pada tahun 2003, indeks persepsi korupsi (IPK) Indonesia hanya 19. Hardirnya KPK tidak dipungkiri telah mendongkrak IPK Indonesia hingga 37 pada tahun 2018 (Transparency International Indonesia, 2018). ${ }^{3}$ Ketua Komisi Pemberantasan Korupsi (KPK) Agus Rajardjo mengatakan, pertumbuhan Indeks Persepsi Korupsi (IPK) di Indonesia paling tinggi dibandingkan negara-negara lain di dunia.

Mungkin terlalu naif dikemukakan harapan keprihatinan nasional melahirkan people power yang menuntut aparat negara untuk memberikan prioritas dalam pemberantasan korupsi. Dan melahirkan kemungkinan rakyat mempunyai posisi tawar yang kuat untuk meminta aparat negara yang tidak dapat menunjukan niat baik dalam memberantas korupsi. Keprihatinan nasional terhadap korupsi dapat terbentuk apabila pemerintah dan aktivis anti korupsi melakukan kampanye secara luas dengan intensitas tinggi.

Pers menjadi media ampuh untuk menggalang kesadaran publik terhadap dampak-dampak korupsi. Seperti terjadi pasca bencana tsunami, pemberitaan pers mampu membangkitkan solidaritas nasional dan melimpahnya keinginan untuk membantu korban tsunami. Hal tersebut dapat dicapai ketika pers menginformasikan dampak yang luar biasa dari gelombang tsunami dengan memporak-porandakan kontruksi bangunan

${ }^{3}$ Harian Haluan .com, Kamis, 25 Juni 2015 19:05:22 WIB Reporter : Tim Redaksi

4 Artikel ini telah tayang di Kompas.com dengan judul "Ketua KPK: Pertumbuhan Indeks Persepsi Korupsi Indonesia Tertinggi di Dunia", https://nasional. kompas. com/read/2018/12/04/10400111/ketua-kpkpertumbuhan-indeks-persepsi-korupsi-indonesiatertinggi-di-dunia. Penulis : Dylan Aprialdo Rachman, Editor : Sandro Gatra 
pada suatu wilayah. Pola yang sama dapat dapat diterapkan pada korupsi, apabila dampak korupsi diinformasikan kepada rakyat bahwa korupsi mengakibatkan antara lain menurunnya kualitas pelayanan yang seharusnya diberikan oleh negara kepada rakyatnya.

\section{PENUTUP}

\section{A. Kesimpulan}

Berdasarkan pembahasan terhadap pokok permasalahan, dapat ditarik kesimpulan sebagai berikut:

1. Tantangan penegakan hukum dalam pemberantasan tindak pidana korupsi antara lain: masih minimnya kepercayaan terhadap aparat penegak hukum; Pemeriksaan kasus tindak pidana korupsi di pengadilan oleh hakim lebih memprioritaskan pada pemenuhan perbuatan melawan hukum formil. Ketiadaan putusan hakim yang menjadi simbol ketegasan dalam pemberantasan korupsi: kesadaran akan dampak korupsi masih terlalu abstrak dan kurang dipahami masyarakat; Perang terhadap korupsi masih sekedar menjadi wacana atau hiburan politis bagi rakyat; ketiadaan atau minimnya kesempatan untuk berpartisipasi dalam pemberantasan korupsi menjadi penyebab masyarakat tidak peduli atau prihatin terhadap pemberantasan korupsi. Selain itu kebiasaan yang sudah melekat bahwa 'kalau semua ingin cepat, uang adalah solusinya' dan budaya yang 'nrimo' atau tidak mau mempermasalahkan segala urusan yang ada kaitannya dengan penyelenggaraan negara, seolah menjadi unsur penyubur dari tumbuh-kembangnya korupsi.

2. Peluang penegakan hukum dalam pemberantasan tindak pidana korupsi antara lain : Diterbitkannya UU No. 31 Tahun 1999 tentang Pemberantasan Tindak Pidana Korupsi; pertumbuhan Indeks Persepsi Korupsi (IPK) di Indonesia paling tinggi dibandingkan negara-negara lain di dunia; adanya keprihatinan nasional terhadap korupsi dapat merangsang pemerintah dan aktivis anti korupsi melakukan kampanye secara luas dengan intensitas tinggi; Pers menjadi media ampuh untuk menggalang kesadaran publik terhadap dampakdampak korupsi.

\section{B. Rekomendasi}

Di tengah upaya pembangunan nasional di berbagai bidang, aspirasi masyarakat untuk memberantas korupsi dan bentuk penyimpangan lainnya semakin meningkat, karena dalam kenyataan adanya perbuatan korupsi telah menimbulkan kerugian negara yang sangat besar yang pada gilirannya dapat berdampak pada timbulnya krisis di berbagai bidang. Untuk itu, upaya pencegahan dan pemberantasan korupsi perlu semakin ditingkatkan dan diintensifkan dengan tetap menjunjung tinggi hak asasi manusia dan kepentingan masyarakat.

\section{Referensi}

Jeremy Pope, Strategi Memberantas Korupsi, alih bahasa Masri Maris, ditertibkan atas kerjasama Transparency International Indonesia dengan Yayasan Obor Indonesia dan TI Indonesia, Jakarta, 2008.

Yakub Adi Krisanto, Tindak Pidana Korupsi , (Usaha) Penegakan Hukum di Republik Korup, Academia, diakses tanggal 21 Januari 2019

Harian Haluan .com, Kamis, 25 Juni 2015 19:05:22 WIB Reporter : Tim Redaksi , diakses tanggal 21 Januari 2019 